\title{
Topiramate in Intractable Childhood Onset Epilepsy - A Cautionary Note
}

\author{
J.M. Dooley, P.R. Camfield, E. Smith, P. Langevin, G. Ronen
}

\begin{abstract}
Objectives: To study the effectiveness and safety of topiramate in clinical practice, for a group of patients with childhood onset epilepsy. Methods: All patients treated with topiramate at the three study centers between November 1995 and December 31, 1997 were analyzed retrospectively, using a standardized study protocol. Data were gathered on demographic features, seizure response and medication related adverse events. Results: Eighty-seven patients were treated with topiramate. Over 90\% seizure reduction was achieved in $8(9 \%)$ patients, 50\%-90\% in $21(24 \%),<50 \%$ in $54(62 \%)$ patients. Four patients $(5 \%)$ had a deterioration in seizure control. Adverse events required topiramate discontinuation in $36(41 \%)$. Of these $27(31 \%)$ complained of unacceptable cognitive dulling. The rate of dose escalation and final dose in $\mathrm{mg} / \mathrm{kg}$ were similar in those who remained on topiramate and those who were intolerant because of cognitive side effects. Conclusions: Although topiramate resulted in $>50 \%$ seizure reduction in 29 (33\%) of this group of patients with difficult epilepsy, its usefulness was limited by a high incidence of adverse effects. Adverse events prevented ongoing therapy for $36(41 \%)$ and cognitive dulling resulted in topiramate discontinuation by 27 (31\%) of the group.
\end{abstract}

RÉSUMÉ: Le topiramate dans l'épilepsie réfractaire de l'enfance - un mot d'avertissement. Objectifs: Le but de cette étude était d'examiner l'efficacité et la sécurité du topiramate en pratique clinique dans le traitement de patients dont l'épilepsie a débuté dans l'enfance. Méthodes: Les dossiers de tous les patients traités par le topiramate dans les trois centres qui participaient à l'étude entre novembre 1995 et le 31 décembre 1997 ont été analysés rétrospectivement au moyen d'un protocole standardisé. Des données sur la démographie, la réponse au traitement et les problèmes de santé associés à la médication ont été recueillies. Résultats: Quatre-vingt-sept patients ont été traités par le topiramate. Une diminution de plus de $90 \%$ des crises a été obtenue chez 8 patients (9\%), 50\%-90\% chez 21 (24\%), <50\% chez 54 (6\%). Chez 4 patients (5\%) le contrôle des crises s'est détérioré. Le topiramate a été cessé chez 36 patients (41\%) à cause de problèmes de santé associés au médicament, dont 27 patients (31\%) qui ont présenté un amoindrissement inacceptable des fonctions cognitives. L'augmentation des doses et la dose finale en $\mathrm{mg} / \mathrm{kg}$ étaient semblables chez ceux qui ont continué à prendre le médicament et chez ceux qui étaient intolérants à cause d'effets secondaires cognitifs. Conclusions: Bien que le topiramate a produit une diminution des crises $>50 \%$ chez 29 patients (33\%) de ce groupe de patients ayant une épilepsie difficile à contrôler, son utilité est limitée par une incidence élevée d'effets secondaires. Les effets secondaires ont motivé l'arrêt de cette médication chez 36 patients (41\%) et l'amoindrissement des fonctions cognitives a été le motif de cet arrêt chez 27 patients (31\%) du groupe.

Can. J. Neurol. Sci. 1999; 26:271-273

Topiramate is a new antiepileptic drug (AED) which was introduced to Canada in 1997. It has multiple modes of action, which include $\mathrm{Na}^{+}$channel blocking, enhancing GABA activation and blocking glutamate receptors. ${ }^{1,2,3}$ This spectrum of anticonvulsant actions suggests that topiramate may be a valuable AED, with a broad therapeutic profile. Despite these theoretical advantages, there are limited clinical data available on topiramate use in pediatric patients. ${ }^{4,5}$

The value of medication in clinical practice may be different to the experience in double-blind trials, which are necessary for licensing purposes. We present the clinical experience with our first 87 patients treated with topiramate to assess its impact in routine clinical practice. Our patients were predominantly children but included some older patients with refractory epilepsy who continued to be followed in the three participating Pediatric Epilepsy Clinics.

\section{METHODS}

The charts of all patients treated with topiramate by the authors between November 1, 1995 and December 31, 1997 were reviewed and analyzed retrospectively. All patients were seen at the IWK Grace Health Centre, Halifax, Nova Scotia, le Centre Hôpital de l'Université, Laval, Quebec or McMaster University, Hamilton, Ontario, Canada.

Using a standardized method, prospectively gathered data were recorded on sex, weight, cognitive ability, seizure type(s) and etiology. The age and dose at topiramate introduction, rate of dose increase and months on topiramate therapy were noted. We documented the final topiramate dose and other AEDs used while the patients were taking topiramate, side effects reported by the families and the reason for discontinuing topiramate for those who stopped therapy by the end of 1997. Seizure response was classified according to the caregivers' evaluation as: 1) seizure free, 2) $>90 \%$ reduction in seizures, 3) $50-90 \%$ improvement, 4) $<50 \%$ improvement and 5) deterioration in

From the Neurology Division, IWK Grace Health Centre, Halifax, NS. RECEIVED FEBRUARY 8, 1999. ACCEPTED IN FINAL FORM MAY 6, 1999 Reprint requests to: J.M. Dooley, Neurology Division, IWK Grace Health Centre, 5850 University Avenue, Halifax, Nova Scotia, Canada B3J 3G9 
seizure control. Those on topiramate who did not have current data available at the time of chart review were contacted by telephone.

Data were analyzed using chi-squared for categorical and ttests for continuous data. The study did not receive financial funding from any pharmaceutical company.

\section{ReSUlts}

There were 87 patients, all with intractable epilepsy. Sixteen had three seizure types, 21 had two varieties of seizures and the remaining 50 patients had a single seizure type (Table 1 ). Twentyfour were on one other AED in addition to topiramate, 36 were on two other AEDs and 19 were on three or more concomitant AEDs. Eight patients had failed all other available AEDs and were on topiramate monotherapy. Twenty-two were cognitively normal, 22 had mild mental retardation, 22 had moderate MR and the remaining 21 had severe cognitive impairment.

The etiology of the neurological deficits and epilepsy varied. Seven had cerebral dysgenesis, five had epilepsy following infectious processes, two post cerebral hypoxia, one had Rett syndrome and one had Opitz-Frias syndrome. Two had epilepsy following therapy for acute lymphocytic leukemia, one had congenital hypothyroidism and another had a cerebral venous angioma. Four had tuberous sclerosis and three severe myoclonic epilepsy of infancy. Nine children had Lennox Gastaut syndrome.

Table 1: Characteristics of 87 patients treated with topiramate

\begin{tabular}{llll}
\hline $\begin{array}{l}\text { Number of } \\
\text { seizure types } \\
\text { at treatment } \\
\text { initiation }\end{array}$ & $\begin{array}{l}\text { Number of } \\
\text { patients }\end{array}$ & $\begin{array}{l}\text { Number of } \\
\text { AEDs in } \\
\text { addition to } \\
\text { topiramate }\end{array}$ & $\begin{array}{l}\text { Number of } \\
\text { patients }\end{array}$ \\
\hline & & $\geq 3$ & 19 \\
23 & 16 & 2 & 36 \\
2 & 21 & 1 & 24 \\
1 & 50 & 0 & 8 \\
\hline
\end{tabular}

Table 2: Seizure characteristics of patients who continued and discontinued topiramate therapy, many patients had more than one seizure type

\begin{tabular}{lrr}
\hline & \multicolumn{3}{c}{ Topiramate Status } \\
& On & Off \\
Seizure Types & & \\
Complex Partial & 27 & 24 \\
Primary and secondarily generalized tonic-clonic & 10 & 20 \\
Absence & 3 & 6 \\
Myoclonic & 5 & 9 \\
Tonic & 1 & 8 \\
Atonic & 4 & 6 \\
& & \\
Seizure Syndromes & & \\
Idiopathic Localization related & 0 & 1 \\
Cryptogenic/symptomatic Localization related & 27 & 31 \\
Idiopathic Generalized & 0 & 1 \\
Cryptogenic/symptomatic generalized & 8 & 16 \\
Undetermined if focal or generalized & 0 & 3 \\
\hline
\end{tabular}

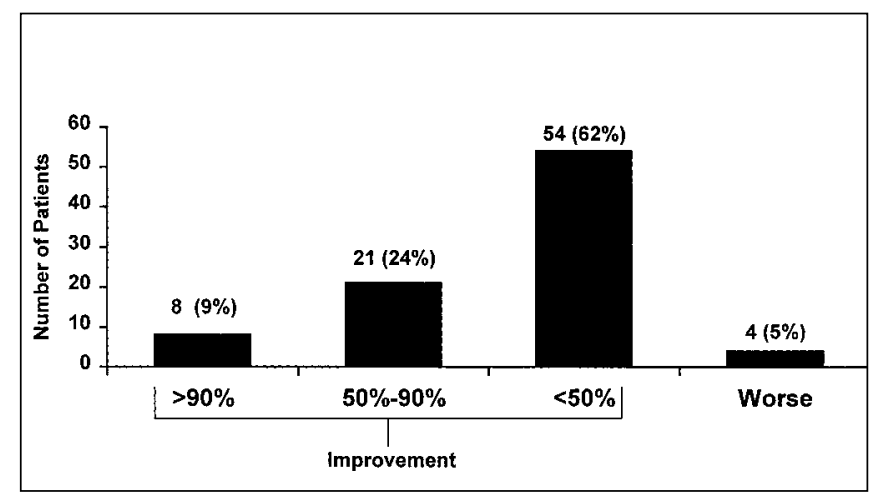

Figure 1: Seizure response for 87 patients treated with topiramate

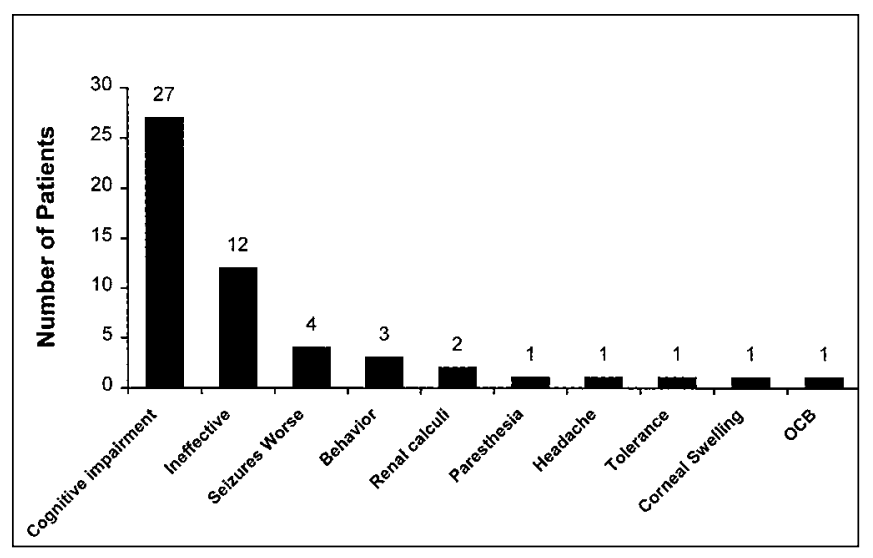

Figure 2: Reasons for discontinuing topirimate in 53 patients (61\%)

Inspection of Table 2 suggests that no seizure type or epilepsy syndrome was markedly more responsive to topiramate (Table 2). When the response rate for complex partial seizures (27 of 51) was compared to all other seizure types ( 23 of 72 ) it appeared that the response rate for complex partial seizures was better $(\mathrm{p}=0.02$ $\chi^{2}$ ). Because many children had more than one seizure type the significance of this finding is unclear. Furthermore there was no significant difference between those with localization-related epilepsy and those with generalized epilepsy. Any further analysis of this issue was inappropriate due to the small sample size.

The mean age at treatment initiation was $12.5 \pm 6.4$ years (range 1-31 years). Of the 87 patients, 34 tolerated topiramate. Seizure freedom was achieved in three patients $(3.4 \%),>90 \%$ reduction in five children $(5.7 \%), 50-90 \%$ in 21 patients $(24.1 \%)$ and $<50 \%$ in 54 patients $(62.1 \%)$. Deterioration in seizure control was seen in four patients $(4.6 \%)$ (Figure 1). One patient with complex partial seizures, refractory to all available AEDs, the ketogenic diet and seizure surgery has been seven months seizure free on topiramate.

Thirty-four $(39.1 \%)$ patients have remained on topiramate. Fifty-three patients stopped topiramate therapy (Figure 2). Twelve patients discontinued treatment because of ineffectiveness, four because of deterioration in seizure control and one because of tolerance, which occurred four months after the initiation of treatment.

Thirty-six (41.4\%) experienced adverse effects, sufficient to 
require topiramate discontinuation. Twenty-seven families (31\%) complained of unacceptable cognitive dulling. Topiramate was discontinued by one patient's family physician because of corneal swelling and one child complained of headaches. A further patient had paresthesia. Three children had behavioral problems, two had renal stones and one had obsessive behaviors. Neither patient with renal stones had been treated with the ketogenic diet. All adverse effects resolved upon topiramate discontinuation.

The overall mean duration of topiramate therapy was 6.74 months (range 0.25-30 months). For those who remained on therapy the mean duration of topiramate treatment was 10.8 months (range 0.25-30 months) compared to 4.4 months (range 0.25-24 months) for those who discontinued therapy. The rate of dose escalation in those who discontinued topiramate because of cognitive side effects tended to be lower (mean $0.71 \mathrm{mg} / \mathrm{kg} / \mathrm{week}$, range $0.31-1.78 \mathrm{mg} / \mathrm{kg} /$ week) than for those who stopped therapy for other reasons (mean $0.92 \mathrm{mg} / \mathrm{kg} /$ week, range 0.22-1.85 $\mathrm{mg} / \mathrm{kg} /$ week $)(\mathrm{p}=0.08)$. The rate of topiramate introduction and dose increase was similar for those without adverse effects (mean $0.64 \mathrm{mg} / \mathrm{kg} /$ week, range $0.22-1.62 \mathrm{mg} / \mathrm{kg} /$ week) and for those who discontinued because of cognitive adverse effects $(\mathrm{p}=0.4)$. The mean dosage for those who remained on topiramate was 4.8 $\mathrm{mg} / \mathrm{kg}$ (range $0.7-11.5 \mathrm{mg} / \mathrm{kg}$ ) compared to a mean dose of 4.0 $\mathrm{mg} / \mathrm{kg}$ (range $0.4-13.1 \mathrm{mg} / \mathrm{kg}$ ) for those who discontinued therapy $(\mathrm{p}=0.14)$. Those who continued on topiramate were taking a mean of 1.73 other AEDs (range 0-3) compared to 2.07 additional AEDs (range 1-4) for those off topiramate $(\mathrm{p}=0.1)$.

\section{Discussion}

Topiramate, a sulfamate-substituted derivative of monosaccharide D-fructose, is distinct from other AEDs and has a novel combination of mechanisms of action. It blocks voltageactivated sodium channels, enhances GABA activation of $\mathrm{GABA}_{\mathrm{A}}$ receptors and GABA-mediated chloride influx, blocks the kainate/AMPA subtype of glutamate receptor and is a weak carbonic anhydrase inhibitor. ${ }^{1,2,3}$ The pharmacokinetic profile of topiramate is also favorable. Its rapid absorption is not influenced by food and it has predictable and linear pharmacokinetics. ${ }^{5}$ Topiramate is approximately $15 \%$ protein bound and has minimal interaction with other AEDs. ${ }^{5}$

Theoretically, therefore, topiramate is a potentially valuable AED with a broad therapeutic profile. Topiramate has been shown to be effective in refractory partial and generalized epilepsies in adults. ${ }^{6,7,8,9,10}$ In five studies reviewed by Marson et al. the overall response ratio for $50 \%$ reduction in seizure frequency was 4.22 (95\% CI: 2.80 to 6.35$).{ }^{11}$ In these five studies, 146 of 360 patients (41\%) achieved $50 \%$ seizure control compared to 17 of 174 on placebo. ${ }^{11}$ Adverse events caused 66 of 360 (18\%) to discontinue topiramate compared to 13 of $134(9.7 \%)$ on placebo. $^{11}$

The value of topiramate may be limited by associated adverse effects. Side effects include "abnormal thinking" which has been found in $25-33 \%$, paraesthesia has been reported in $19 \%$ and renal stones in $1.5 \% .^{12}$
In our group of patients with intractable epilepsy, topiramate produced $>50 \%$ reduction in seizure frequency in $33.1 \%$ (29 patients). For eight children the improvement was $>90 \%$. The usefulness of topiramate was limited in our patients by the occurrence of adverse effects. Cognitive dulling was the most significant difficulty encountered. Families did not report sleepiness but rather a difficulty initiating and completing intellectual tasks. Corneal swelling was diagnosed by one child's family physician but was not confirmed by an ophthalmologist.

Our study reports experience in clinical practice. Although we did not use standardized tests of cognition or quality of life, we were very impressed clinically by the degree of cognitive dulling which was reported by families. Our prior clinical impression that such cognitive impairment was related to the rate of dose escalation was not supported by our analysis. The differences in rates of dose increase or weight related dose were not statistically significant, in those who remained on topiramate and those who were not able to tolerate topiramate because of intellectual dulling.

In summary, about one-third of our patients with refractory epilepsy had a potentially useful reduction in seizure frequency. Our small sample size and retrospective study design precluded any clear definition of the clinical profile of responders. We urge a cautious approach to the use of topiramate because caretakers reported such a high rate of cognitive dysfunction.

\section{REFERENCES:}

1. White HS, Brown D, Skeen GA, Wolf HH, Twyman RE. The anticonvulsant topiramate displays a unique ability to potentiate GABA-evoked chloride currents. Epilepsia 1995;36(Suppl 3):S39.

2. White HS, Brown D, Skeen GA, Twyman RE. The investigational anticonvulsant topiramate potentiates GABA-evoked currents in mouse cortical neurons. Epilepsia 1995;36(Suppl 4):S34.

3. Severt L, Coulter DA, Sombati S, DeLorenzo RJ. Topiramate selectively blocks kainate currents in cultured hippocampal neurons. Epilepsia 1995;36(Suppl 4):S38.

4. Glauser TA. Preliminary observations on topiramate in pediatric epilepsies. Epilepsia 1997;38(Suppl 1):S37-S41.

5. Glauser TA. Topiramate use in pediatric patients. Can J Neurol Sci 1998;25:S8-S12.

6. Johannessen SI. Pharmacokinetic and interaction profile of topiramate: review and comparison with other newer antiepileptic drugs. Epilepsia 1997;38(Suppl 1):S18-S23.

7. Faught E. Efficacy of topiramate as adjunctive therapy in refractory partial seizures: United States trial experience. Epilepsia 1997;38(Suppl 1):S24-S27.

8. Ben-Menachem E. Clinical efficacy of topiramate as add-on therapy in refractory partial epilepsy: the European experience. Epilepsia 1997;38(Suppl 1):S28-S30.

9. Rosenfeld WE, Sachdeo RC, Faught RE, Privitera M. Long-term experience with topiramate as adjunctive therapy and as monotherapy in patients with partial onset seizures: retrospective survey of open-label treatment. Epilepsia 1997;38(Suppl 1):S34-S36.

10. Biton V. Preliminary open-label experience with topiramate in primary generalized seizures. Epilepsia 1997;38(Suppl 1):S42-S44.

11. Marson AG, Kadir ZA, Chadwick DW. New antiepileptic drugs: a systematic review of their efficacy and tolerability. Br Med J 1996;313:1169-1174.

12. Jones MW. Topiramate - safety and tolerability. Can J Neurol Sci 1998;25:S13-S15 